\title{
HOMENAGEM
}

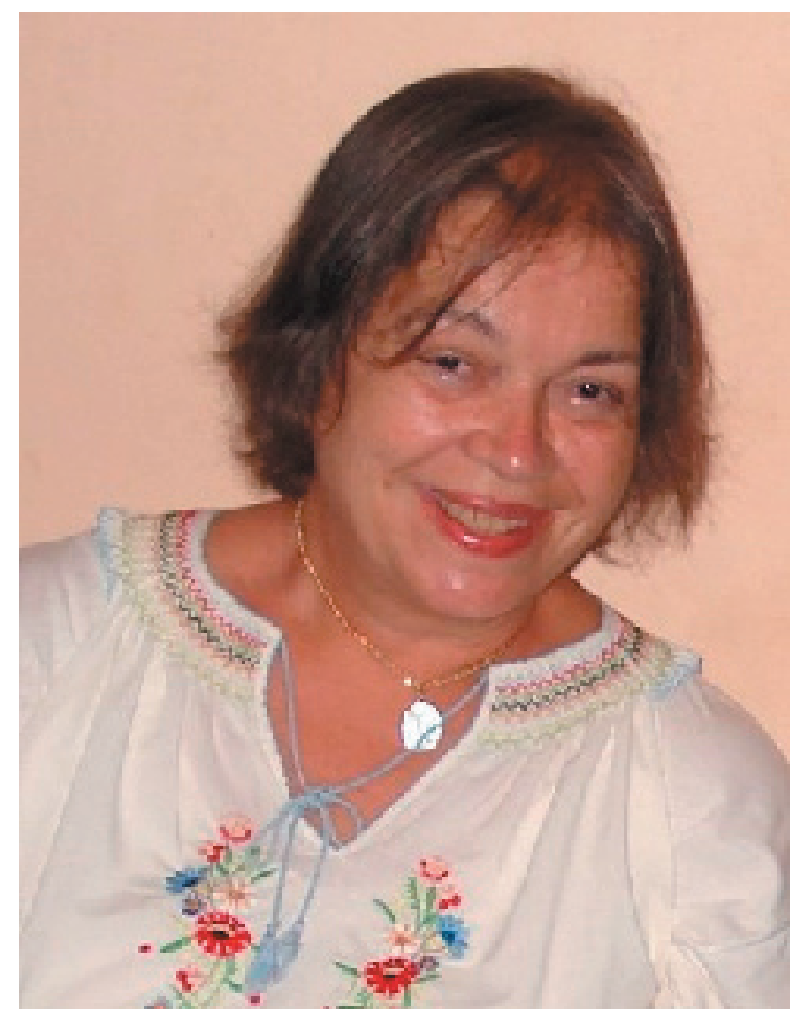

\section{Maria Esmeralda Soares Payão Demattê}

Por ocasião do $17^{\circ}$ Congresso Brasileiro de Floricultura e Plantas Ornamentais, realizado em Aracaju, em setembro de 2009, a Sociedade Brasileira de Floricultura e Plantas Ornamentais, que completava 30 anos de criação, homenageou Maria Esmeralda Soares Payão Demattê.

Esmeralda tem descrito, em seu Currículo Lattes, sua formação como Engenheira Agrônoma na Escola Superior de Agricultura Luiz de Queiroz da Universidade de São Paulo (1966), onde também cursou mestrado em Fitotecnia (1978) e doutorado em Agronomia, Área de Solos e Nutrição de Plantas (1983). Especializou-se em produção de hortaliças no International Agricultural Centre, Wageningen, Holanda, em 1972, e em paisagismo, na Faculdade de Arquitetura e Urbanismo da Universidade de São Paulo, em 1981. Foi pesquisadora do Instituto Agronômico (IAC), entre 1968 e 1974, e docente da Universidade Estadual Paulista Júlio de Mesquita Filho (Unesp), Faculdade de Ciências Agrárias e Veterinárias, Departamento de Produção Vegetal, de 1974 a 1998, quando se aposentou. Atualmente, é professora voluntária do Departamento de Produção Vegetal nessa mesma Faculdade. Tem experiência na área de Agronomia, atuando principalmente em paisagismo, conservação de espécies nativas, substratos alternativos ao xaxim, cultivo de orquídeas e bromélias, reflorestamento heterogêneo com espécies nativas, sistemas agroflorestais e recuperação de áreas degradadas. Dedica-se também a artes e, recentemente, a Museologia.

Sua participação na Sociedade Brasileira de Floricultura e Plantas Ornamentais é extremamente rica e configura-se como estímulo e exemplo às gerações futuras. Sócia fundadora, participou de inúmeras Comissões Organizadoras e Executivas de eventos patrocinados pela SBFPO, tendo presidido o $1^{\circ}$ Simpósio Internacional sobre Palmeiras Ornamentais, realizado em Jaboticabal em 1993. Integrou diretorias da SBFPO e a presidiu entre 1995 e 1999 (6a Diretoria). Vem também integrando as Comissões Editoriais da Revista Brasileira de Horticultura Ornamental, atuando desde a sua criação como Editora de Área e contribuindo sobremaneira com a revisão de artigos.

Indubitavelmente, ao lado de sua qualificação profissional, deve ser destacada a sua personalidade afável e generosa, que a torna, no transcorrer dos anos, grande colecionadora de amigos e admiradores, aos quais brinda com seu conhecimento e sempre com um grande estímulo à realização das atividades. Esmeralda é personalidade da floricultura brasileira a ser imitada. 